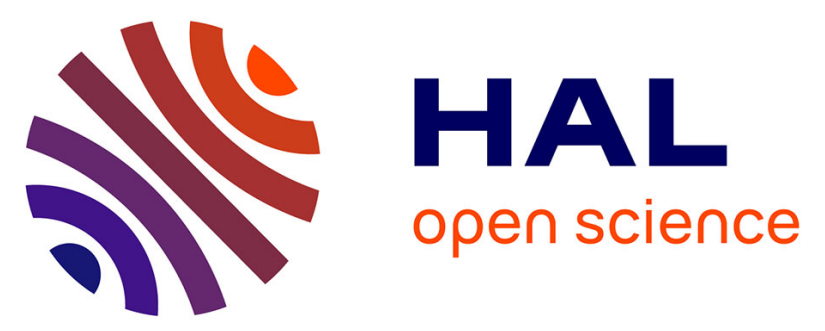

\title{
Synergistic activity of antibiotics combined with ivermectin to kill body lice
}

Abdoul Karim Sangare, Jean-Marc Rolain, Jean Gaudart, Pascal Weber, Didier Raoult

\section{To cite this version:}

Abdoul Karim Sangare, Jean-Marc Rolain, Jean Gaudart, Pascal Weber, Didier Raoult. Synergistic activity of antibiotics combined with ivermectin to kill body lice. International Journal of Antimicrobial Agents, 2016, 10.1016/j.ijantimicag.2016.01.001 . hal-01307125

\section{HAL Id: hal-01307125 \\ https://hal-amu.archives-ouvertes.fr/hal-01307125}

Submitted on 26 Apr 2016

HAL is a multi-disciplinary open access archive for the deposit and dissemination of scientific research documents, whether they are published or not. The documents may come from teaching and research institutions in France or abroad, or from public or private research centers.
L'archive ouverte pluridisciplinaire HAL, est destinée au dépôt et à la diffusion de documents scientifiques de niveau recherche, publiés ou non, émanant des établissements d'enseignement et de recherche français ou étrangers, des laboratoires publics ou privés.

\section{(1) (1) $\$$}

Distributed under a Creative Commons Attribution - NonCommercial - NoDerivatives 44.0 


\title{
Synergistic activity of antibiotics combined with ivermectin to kill body lice
}

\author{
Abdoul Karim Sangaré ${ }^{a}$, Jean Marc Rolain ${ }^{a}$, Jean Gaudart ${ }^{\mathrm{b}}$, Pascal Weber ${ }^{\mathrm{a}}$, \\ Didier Raoult ${ }^{\mathrm{a}, *}$ \\ a Aix-Marseille Université, IHU Méditerranée Infection, URMITE, UM63, CNRS 7278, IRD 198, INSERM 1095, Faculté de Médecine et de Pharmacie, \\ 27 Bd. Jean Moulin, 13385 Marseille cedex 5, France \\ ${ }^{\mathrm{b}}$ Aix-Marseille Université, UMR912 SESSTIM (AMU-Inserm-IRD), Department of Public Health and Medical Information, \\ Centre Hospitalier Universitaire La Timone, 13005 Marseille, France
}

\section{A R T I C L E I N F O}

\section{Article history:}

Received 26 October 2015

\section{Keywords:}

Pediculus humanus humanus

Antibiotics

Ivermectin

Synergistic treatment

\begin{abstract}
A B S T R A C T
Ivermectin and doxycycline have been found to be independently effective in killing body lice. In this study, 450 body lice were artificially fed on a Parafilm ${ }^{\mathrm{TM}}$ membrane with human blood associated with antibiotics (doxycycline, erythromycin, rifampicin and azithromycin) alone and in combination with ivermectin. Fluorescence in situ hybridisation and spectral deconvolution were performed to evaluate bacterial transcriptional activity following antibiotic intake by the lice. In the first series, a lethal effect of antibiotics on lice was observed compared with the control group at 18 days (log-rank test, $P \leq 10^{-3}$ ), with a significant difference between groups in the production of nits $(P=0.019$, Kruskal-Wallis test). A high lethal effect of ivermectin alone $(50 \mathrm{ng} / \mathrm{mL}$ ) was observed compared with the control group (log-rank test, $P \leq 10^{-3}$ ). Fluorescence of bacteriocytes in lice treated with $20 \mu \mathrm{g} / \mathrm{mL}$ doxycycline was lower than in untreated lice $(P<0.0001$, Kruskal-Wallis test). In the second series with antibiotic-ivermectin combinations, a synergistic lethal effect on treated lice (log-rank test, $P<10^{-6}$ ) was observed compared with the control group at 18 days, associated with a significant decrease in the production of nits $(P \leq 0.001$, Kruskal-Wallis test). Additionally, survival of lice in the combination treatment groups compared with ivermectin alone was significant (log-rank test, $P=0.0008$ ). These data demonstrate that the synergistic effect of combinations of antibiotics and ivermectin could be used to achieve complete eradication of lice and to avoid selection of a resistant louse population.
\end{abstract}

(c) 2016 Elsevier B.V. and the International Society of Chemotherapy. All rights reserved.

\section{Introduction}

The body louse Pediculus humanus humanus is a strictly human parasite, living and multiplying in clothing; their infestation is associated with cold weather and a lack of hygiene [1]. Its prevalence reflects the socioeconomic level of the society [2]. In developed countries, infestation is more common among the homeless population and varies from $7 \%$ to $22 \%$ [3]. Body lice are extremely contagious and pose a serious public health problem. They are vectors of the pathogens Rickettsia prowazekii, Bartonella quintana and Borrelia recurrentis, which are responsible for epidemic typhus, trench fever and relapsing fever, respectively $[1,4]$, and they may be considered a plague [5].

\footnotetext{
* Corresponding author. Tel.: +33 4913243 75; fax: +334913877 72

E-mail address: didier.raoult@gmail.com (D. Raoult).
}

For decades, several antibiotics have proved to be effective in the treatment of louse-borne diseases. A single dose of $200 \mathrm{mg}$ doxycycline can cure patients suffering from $R$. prowazekii-induced typhus [6], and $500 \mathrm{mg}$ of tetracycline or erythromycin is optimal therapy for the treatment of $B$. recurrentis infections [7]. Azithromycin has been recommended for the treatment of $B$. quintana infections [8]. In addition, rifampicin was shown to be effective against some intracellular bacteria [9]. These results indicate the potential of antibiotics for the management of louse-borne diseases. Recently, we demonstrated the in vitro efficacy of doxycycline at different doses on body lice and found that doxycycline has a direct effect on endosymbionts of lice through the mycetome switch [10].

Several strategies for eradication of these parasites have been used to avoid the spread and/or outbreak of these diseases. However, some products have already shown their limits. The resistance of lice to lindane in Europe, Africa and Asia [11] and to DDT in Korea and Japan $[12,13]$ has been reported. Pyrethroids have been widely used, however resistance to these compounds has emerged and 
spread over the last decade. In the head louse, resistance to permethrin was first reported in France in 1994 and throughout the world thereafter [14]. Ivermectin is a synthetic derivative of the antiparasitic class of compounds known as avermectins [15]. Resistance to ivermectin and related drugs is an increasing problem for parasite control [16]. Previous studies have associated ATP-binding cassette $(A B C)$ transporters with drug resistance in nematodes [17] and arthropods [18]. However, resistance to ivermectin has also been documented in insects and mites of plants [19] and in nematodes [16]. Resistance to ivermectin has been documented in Rhipicephalus (Boophilus) microplus ticks in Mexico [20]. The occurrence of resistance to macrocyclic lactones has been reported in other arthropods [21]. Used in scabies, clinical and in vitro resistance have been documented in two patients who received 30 and 58 doses of ivermectin, respectively [22].

Today, post-therapeutic re-infestation of the vector of diseases (lice) is common and still remains a real challenge, thus there is a need to develop new therapeutic strategies to avoid these re-infestations. It was observed that avermectin B1a could act synergistically with the antibiotic meticillin to kill meticillin-resistant Staphylococcus aureus (MRSA), rendering the bacteria once again vulnerable to meticillin [23]. The hypothesis that the bacterial symbiont Candidatus Riesia pediculicola is a possible target for the development of louse control strategies [24] was recently confirmed in our previous work [10]. In this study we aimed to demonstrate the in vitro combination of ivermectin with several antibiotics as a synergistic association to achieve complete eradication of lice and to avoid the selection of a resistant population of lice.

\section{Materials and methods}

\subsection{Louse feeding system in vitro}

A long-established inbred line of the human body louse ( $P$. $h$. corporis, Orlando strain), which had been bred on rabbits in a laboratory pet shop by our URMITE team in Marseille, France, was used as a model in the experiments in this study [25]. A Hemotek $^{\mathrm{TM}}$ feeding system (Discovery Workshops, Accrington, UK) with a Parafilm ${ }^{\mathrm{TM}}$ membrane (Chicago, IL), a PS5A/220 Power Unit (Hemotek $^{\mathrm{TM}}$ 5W1 System; Discovery Workshops) and six heating units was used (Fig. 1). A square of synthetic feeding membrane measuring ca. $3 \mathrm{~cm} \times 3 \mathrm{~cm}$ was stretched around the aperture of the blood meal reservoir and was secured with an O-ring (Fig. 1a). The feeding area was sufficient for 100 lice (Fig. 1b). The blood meal reservoir was removable for easy cleaning and autoclaving if necessary. The system does not use animal hosts and enables modification of the meal by introduction of chemicals or infectious agents and accurate adjustment of the temperature through heating units (Fig. 1c) connected directly to the power unit (Fig. 1d). Lice were fed every day at $37^{\circ} \mathrm{C}$ for $1 \mathrm{~h}$ (Fig. 1e).

\subsection{Preparation of blood meal supplemented with antibiotics and ivermectin}

Human blood group A rhesus positive $\left(\mathrm{A}^{+}\right)$[code 74883 from the French Blood Service (EFS)] was used. Ethical approval for the use of human blood in vitro was obtained from the Laboratory Research Ethics Board of Molecular Hematology, EFS. Blood was distributed into $5 \mathrm{~mL}$ tubes and was kept at $-20^{\circ} \mathrm{C}$ before use. The blood was warmed in a water bath at $37^{\circ} \mathrm{C}$ for $30 \mathrm{~min}$ before use. Drugs used were in injectable and oral form as follows: doxycycline $20 \mathrm{mg} / \mathrm{mL}$ (Vibraveineuse ${ }^{\circledR}$ batch A262408; Laboratoires SERB, Paris, France); erythromycin $1 \mathrm{~g}$ (Erythrocine ${ }^{\circledR}$ batch 24370TB22; Amdipharm Ltd., Dublin, Ireland); rifampicin $600 \mathrm{mg}$ (Rifadine ${ }^{\circledR}$ batch A3468; Sanofi-Aventis, Paris, France); azithromycin $600 \mathrm{mg}$ (Azadose ${ }^{\circledR}$ batch 490004; Pfizer Holding, Paris, France); and ivermectin $10 \mathrm{mg} / \mathrm{mL}$ (Ivomec ${ }^{\circledR}$ batch BM295/12; Merial, Lyon, France). For each group of lice, $15 \mu \mathrm{L}$ of uncombined antibiotic diluted at concentrations (doxycycline $20 \mu \mathrm{g} / \mathrm{mL}$, erythromycin $4 \mu \mathrm{g} / \mathrm{mL}$, rifampicin $10 \mu \mathrm{g} / \mathrm{mL}$ and azithromycin $8 \mu \mathrm{g} / \mathrm{mL}$ ) previously established for the first series of experiments was added to a volume of $1.485 \mathrm{~mL}$ of haemolysed blood. In the second series for each group of lice, $15 \mu \mathrm{L}$ of antibiotic (doxycycline $20 \mu \mathrm{g} / \mathrm{mL}$, erythromycin $4 \mu \mathrm{g} / \mathrm{mL}$, rifampicin $10 \mu \mathrm{g} / \mathrm{mL}$ and azithromycin $8 \mu \mathrm{g} / \mathrm{mL}$ ) plus $15 \mu \mathrm{L}$ of ivermectin diluted at a concentration $(50 \mathrm{ng} / \mathrm{mL})$ previously established was added to a volume of $1.470 \mathrm{~mL}$ of haemolysed blood. The final volume of $1.5 \mathrm{~mL}$ obtained for each concentration was introduced into different reservoirs. The reservoir was then attached to the feeder by screwing it onto a nylon stud on the heat transfer plate at the bottom of the feeder.

\subsection{Monitoring of lice and nits}

In total, 450 adult lice [excluding 10 lice sacrificed as live controls in fluorescence in situ hybridisation (FISH)] were used in the experiments. Lice were divided into groups of 45 , were placed on a piece of black cloth and were kept in jars in an oven at $29^{\circ} \mathrm{C}$ and $90 \%$ humidity as breeding lice. The first series of experiments was performed without combination of drugs and the second was based on the antibiotic-ivermectin combinations. A group of lice treated with ivermectin alone was monitored in parallel with the combination series. The control group was fed exclusively with blood without drugs throughout the experiments. Lice were placed on the membrane daily for $1 \mathrm{~h}$ of blood meal feeding. Every day, survival was determined by assessing the number of nits in each group and was recorded on a data collection sheet before the next meal (Supplementary Tables S1 and S2). All of the experiments were repeated three times for reproducibility.

Supplementary Tables S1 and S2 related to this article can be found, in the online version, at http://dx.doi.org/10.1016/j. ijantimicag.2016.01.001.

\subsection{Fluorescence in situ hybridisation (FISH)}

For the FISH technique, the aim was to highlight the effect of the antibiotic (especially doxycycline) on the louse endosymbiont as previously demonstrated [10]. Thus, ten specimens were tested in each untreated group (living controls and dead controls) and in the doxycycline $20 \mu \mathrm{g} / \mathrm{mL}$ group (Table 1). Following fixation, samples were decolourised in $6 \% \mathrm{H}_{2} \mathrm{O}_{2}$ in ethanol for $2 \mathrm{~h}$ and were then placed in hybridisation buffer [ $20 \mathrm{mM}$ Tris- $\mathrm{HCl}$ ( $\mathrm{pH} 8.0$ ), $0.9 \mathrm{M}$ $\mathrm{NaCl}, 0.01 \%$ sodium dodecyl sulphate and $30 \%$ formamide] containing $10 \mathrm{pmol}$ of fluorescent probe $/ \mathrm{mL}$ based on the Candidatus Riesia pediculicola 16S rRNA sequence: Cy3-Lice1255R (5'-Cy3TTGGCTCGCTCTTACGAGT-3') [10].

\subsection{Light and confocal microscopy}

The spectral deconvolution technique was used to differentiate autofluorescence caused by chitin from clean fluorescence. First, the louse was marked and mounted between slide and cover slip and imaging was performed as follows using a Leica SP5 AOBS ${ }^{\circledR}$ confocal resonant scanner (Leica Microsystems, Mannheim, Germany) in Lambda mode. The sample was scanned on a total band of $160 \mathrm{~nm}$ and a slit width of $5 \mathrm{~nm}$ taking care to never saturate the signal. Fluorescence measurement was defined as the extraction of curves (one for fluorescence and one for autofluorescence). After creation of the reference curves, all acquisitions were made with exactly the same settings for gain, offset, laser power and objective. For each acquisition, 32 pictures were collected. Once the references were 

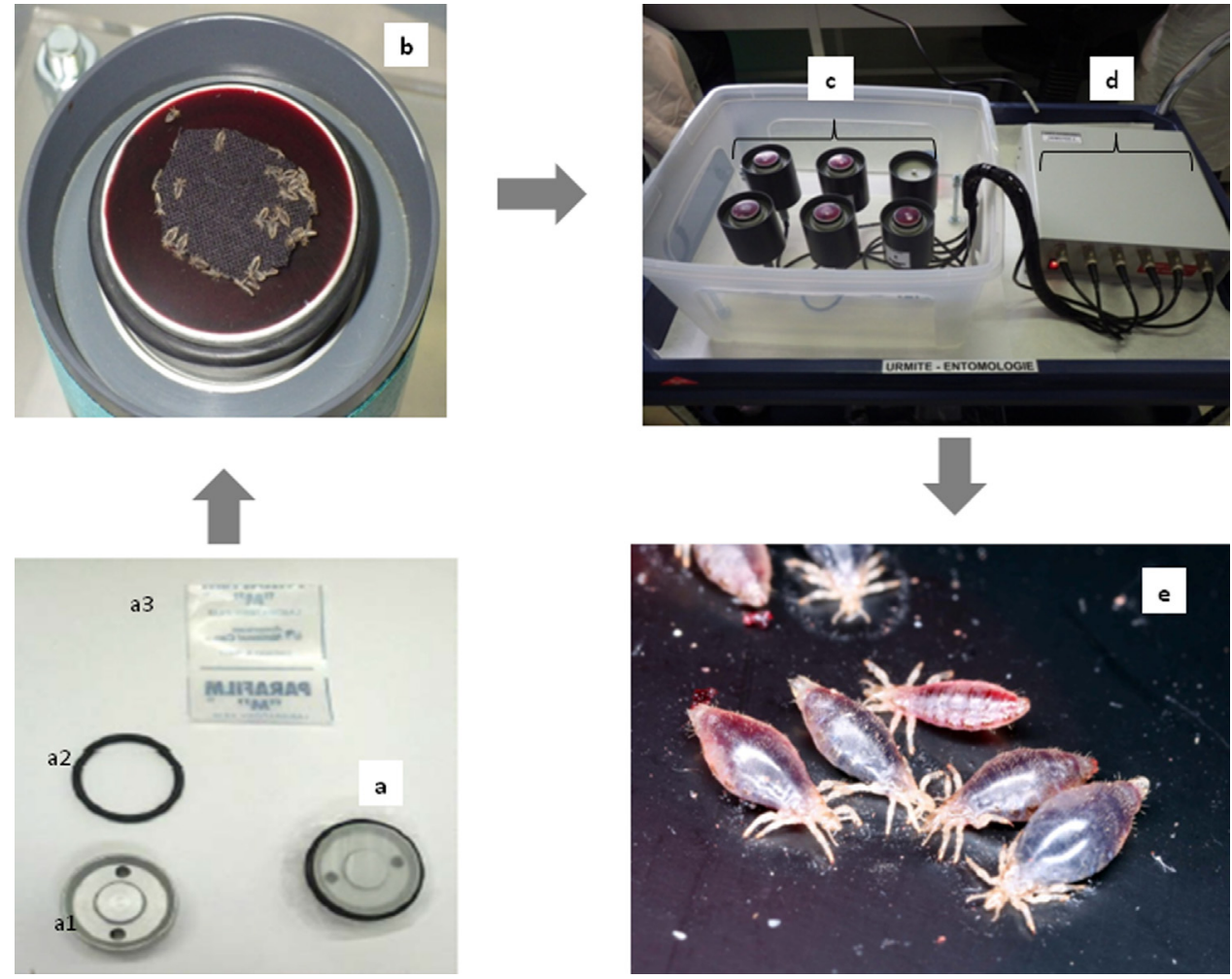

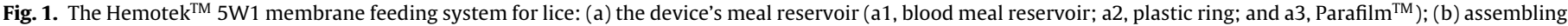
the device; (c) the heating units; (d) the PS5 power unit; and (e) blood meal feeding of lice on artificial membrane.

Table 1

Measurement of fluorescence intensity in three populations of lice.

\begin{tabular}{|c|c|c|c|c|}
\hline Group & Day & Total area & Surface marked & Intensity ratio \\
\hline Doxycycline & 1 & 16,217 & 1205 & 7.4 \\
\hline \multirow{9}{*}{$20 \mu \mathrm{g} / \mathrm{mL}$} & 2 & 4808 & 325 & 6.7 \\
\hline & 3 & 29,970 & 1385 & 5.9 \\
\hline & 4 & 32,994 & 2179 & 6.6 \\
\hline & 5 & 19,730 & 1190 & 6 \\
\hline & 6 & 29,211 & 1537 & 5.2 \\
\hline & 7 & 51,047 & 2468 & 4.8 \\
\hline & 8 & 20,479 & 1216 & 4.6 \\
\hline & 9 & 37,185 & 1231 & 3.3 \\
\hline & 10 & 16,231 & 395 & 2.4 \\
\hline \multirow{10}{*}{$\begin{array}{l}\text { Dead } \\
\text { con- } \\
\text { trols }\end{array}$} & 1 & 8977 & 1462 & 16.2 \\
\hline & 2 & 9523 & 1275 & 13.3 \\
\hline & 3 & 9488 & 1358 & 14.3 \\
\hline & 4 & 13,279 & 1755 & 13.2 \\
\hline & 5 & 12,391 & 1518 & 12.2 \\
\hline & 6 & 9873 & 1280 & 12.9 \\
\hline & 7 & 9173 & 1051 & 11.4 \\
\hline & 8 & 10,506 & 1163 & 11 \\
\hline & 9 & 9923 & 986 & 9.9 \\
\hline & 10 & 12,675 & 1269 & 10 \\
\hline \multirow{10}{*}{$\begin{array}{l}\text { Living } \\
\text { con- } \\
\text { trols }\end{array}$} & 1 & 12,861 & 1943 & 15.1 \\
\hline & 2 & 12,496 & 1605 & 12.8 \\
\hline & 3 & 11,058 & 1467 & 13.2 \\
\hline & 4 & 7558 & 1249 & 16.5 \\
\hline & 5 & 10,913 & 1134 & 10.3 \\
\hline & 6 & 7945 & 1156 & 14.5 \\
\hline & 7 & 8962 & 1580 & 17.6 \\
\hline & 8 & 12,381 & 1397 & 11.2 \\
\hline & 9 & 9914 & 1290 & 13 \\
\hline & 10 & 13,091 & 1898 & 14.4 \\
\hline
\end{tabular}

determined and assigned, the samples were spectrally deconvolved and the signals were separated by assigning them a distinct colour.

\subsection{Calculation of intensity ratios}

MetaMorph v.4.6 (Molecular Devices, Sunnyvale, CA) and a generated Excel table (Microsoft Corp., Redmond, WA) were used to calculate the intensity ratios.

\subsection{Statistical analysis}

Data were stored in Excel. Analyses were performed with $\mathrm{R}$ software v.3.1.1 (R Foundation for Statistical Computing, Vienna, Austria). Kaplan-Meier estimations and log-rank test were used for survival analysis. Analysis of Kruskal-Wallis non-parametric test was used for mean comparisons. Bonferroni correction was applied for subgroup tests. The statistical tests represent bilateral situations, and $P$-values of $\leq 0.05$ were considered significant.

\section{Results}

Feeding lice on artificial membranes enabled them to be treated with antibiotics and ivermectin. The blood feeding rate was $>95 \%$ in all treatment arms (Fig. 1e).

\subsection{Effect of antibiotics on the survival of lice and on nit production}

To determine the effect of antibiotics, in the first series of experiments each group of lice treated with either doxycycline $20 \mu \mathrm{g} / \mathrm{mL}$, erythromycin $4 \mu \mathrm{g} / \mathrm{mL}$, rifampicin $10 \mu \mathrm{g} / \mathrm{mL}$ or azithromycin $8 \mu \mathrm{g} / \mathrm{mL}$ as well as the controls were followed until the end. Survival of lice in the control group was significantly different from survival in the treated groups (log-rank test, $P \leq 10^{-3}$ ) 

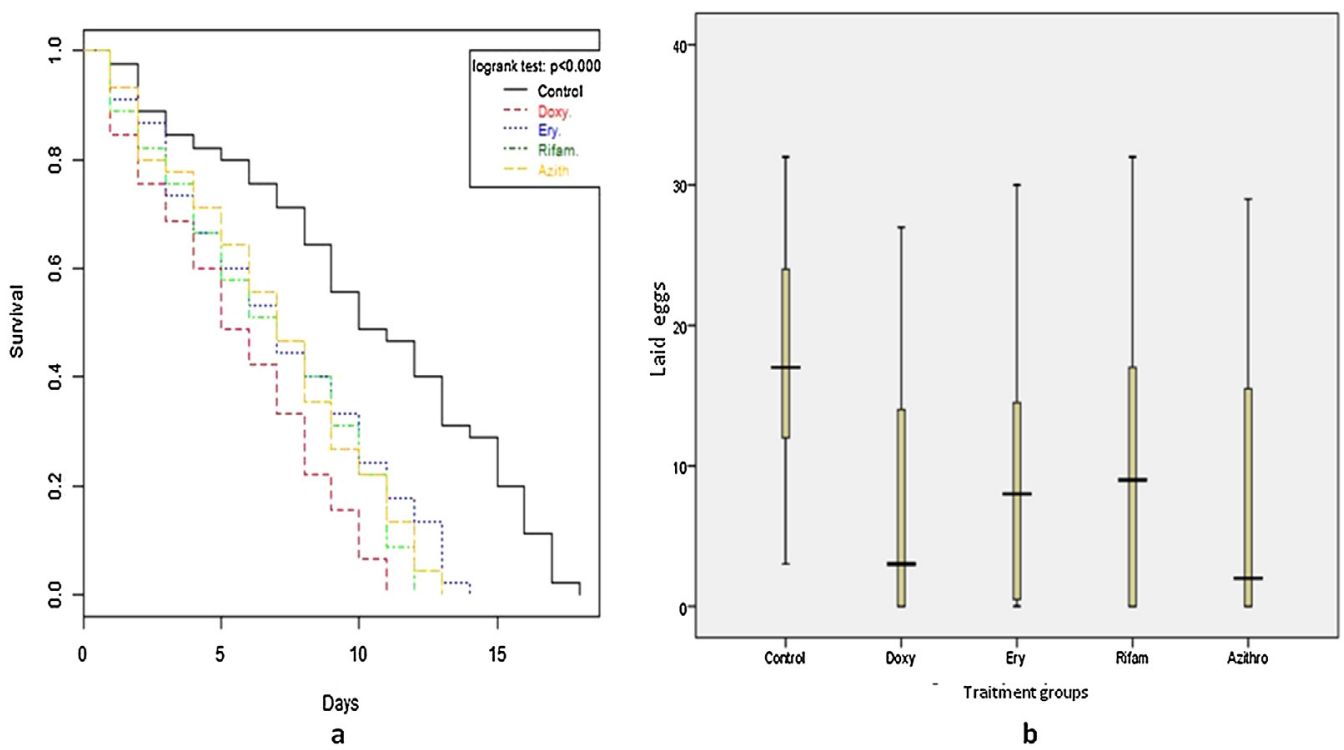

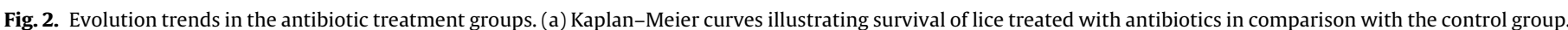

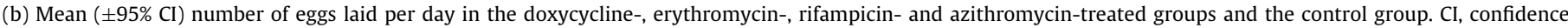
interval; Doxy, doxycycline; Ery, erythromycin; Rifam, rifampicin; Azith/Azithro, azithromycin.

(Fig. 2a). Moreover, a decrease in the production of nits was observed in the treated groups compared with the control group (Fig. 2b), with mean [95\% confidence interval (CI)] number of eggs laid per day of 7.5 (2.5-12.5), 9.8 (4.3-15.3), 10 (4.6-15.6), 7.7 (2.2-13.2) and $17.8(13.3-22.3)$ in the doxycycline-, erythromycin, rifampicin- and azithromycin-treated groups and the control group, respectively. The difference in mean nit production was significant between the groups ( $P=0.019$, Kruskal-Wallis test).

\subsection{Direct effect of doxycycline on the lice mycetome analysed through FISH}

To show that doxycycline affects the louse's endosymbionts, we focused on a new analysis based on spectral deconvolution to calculate the ratios between the two signals (Table 1). By using the function extraction curve computation of reply in emission and positioning the reference areas on distinctive signals, two curves were extracted: one for specific fluorescence of the bacterium and one for autofluorescence of the louse. Thus, the results show that bacterial fluorescence in the group treated with doxycycline $20 \mu \mathrm{g} / \mathrm{mL}$ (Fig. 3a) was lower than in the untreated groups (living and dead controls) (Fig. $3 \mathrm{~b}$ and c) $(P<0.0001$, Kruskal-Wallis test).

\subsection{Effect of ivermectin alone on the survival of lice and production of nits}

To determine the antiparasitic action of ivermectin alone, lice treated with $50 \mathrm{ng} / \mathrm{mL}$ ivermectin were followed until the end of the experiment. A high mortality rate was found compared with the control group (log-rank test, $P \leq 10^{-3}$ ) at 18 days (Fig. 4a). A significant difference between groups was observed in mean nit production $(P=0.001$, Kruskal-Wallis test), with mean $(95 \% \mathrm{CI})$ number of eggs laid per day of $5.2(0.6-9)$ and 17.8 (13.3-22.3), respectively (Fig. 4b).

\subsection{Synergistic effect of antibiotics and ivermectin on survival of lice and production of nits}

To determine the antiparasitic synergistic action of ivermectin combined with antibiotics, in a second series of experiments five groups of lice were tested for their survival kinetics. In the combination groups (doxycycline $20 \mu \mathrm{g} / \mathrm{mL}+$ ivermectin $50 \mathrm{ng} / \mathrm{mL}$, erythromycin $4 \mu \mathrm{g} / \mathrm{mL}+$ ivermectin $\quad 50 \mathrm{ng} / \mathrm{mL}$, rifampicin $10 \mu \mathrm{g} / \mathrm{mL}+$ ivermectin $50 \mathrm{ng} / \mathrm{mL}$ or azithromycin $8 \mu \mathrm{g} / \mathrm{mL}+$ ivermectin $50 \mathrm{ng} / \mathrm{mL}$ ), lice were more rapidly killed compared with the control group, exhibiting potent synergistic action (log-rank test, $P<10^{-6}$ ) (Fig. 5a). Moreover, a significant decrease in the production of nits was observed in the combination groups compared with the control group (Fig. 5b), with mean (95\% CI) eggs per day of 2.4 ( -0.9 to 5.8 ), 4.4 ( -0.1 to 9.0 ), 4.0 ( -0.6 to 8.6 ), 3.6 ( -0.5 to 7.7 ) and 17.8 (13.3-22.3), respectively. Thus, the difference in mean production of nits between groups was significant $(P \leq 0.001$, Kruskal-Wallis test). Moreover, overall survival of lice in the combination treatment groups compared with ivermectin alone was also significant (log-rank test, $P=0.0008$ ) (Fig. 6a). Therefore, the difference was significant when comparing the combination groups with the ivermectin and control groups (Fig. 6b).

\section{Discussion}

For decades, complete eradication of human lice has remained challenging. In the first in vitro series of experiments, the lethal effect of the antibiotics doxycycline, erythromycin, rifampicin and azithromycin on lice was observed compared with the control group at 18 days, associated with a decrease in the production of nits. Of the four antibiotics tested, doxycycline appeared to be more effective than rifampicin, azithromycin and erythromycin, with a variable survival time according to treatment group (Fig. 2a; Supplementary Table S1). Recently, the in vitro efficacy of doxycycline at different doses on body lice was demonstrated [10]. In light of these results, we can suggest that the use of antibiotics (doxycycline, rifampicin, azithromycin and erythromycin) alone or in combination could be an efficient way to develop new drugs and to overcome drug resistance in lice.

Several decades ago it was demonstrated that body lice depend on obligate endosymbionts to supplement their nutritionallydeficient blood diet [26]. However, they maintain organs called mycetomes that house the primary endosymbiont [27]. Thus, through FISH analysis we were able to demonstrate that damage to the symbiont bacteria caused the death of their host as confirmed 

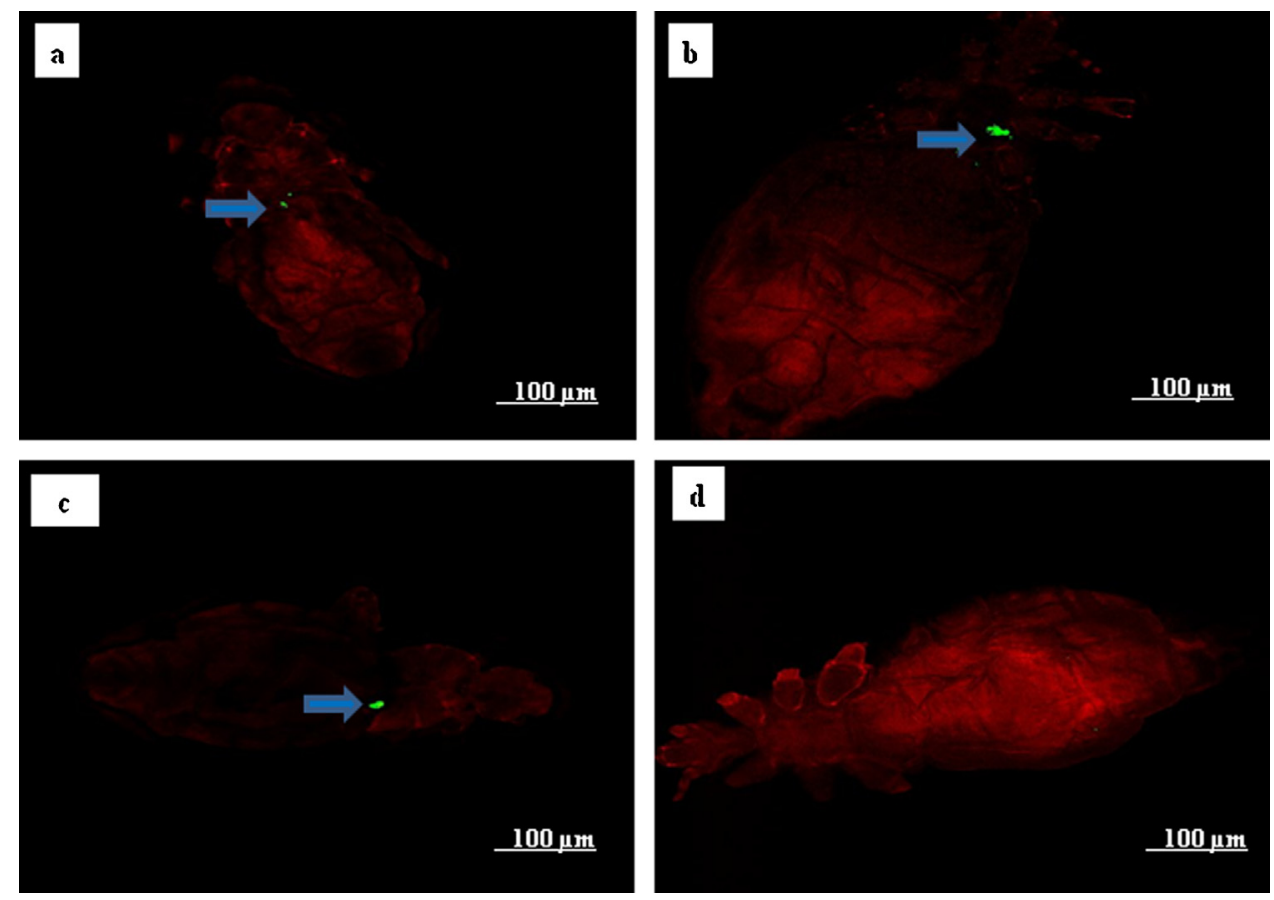

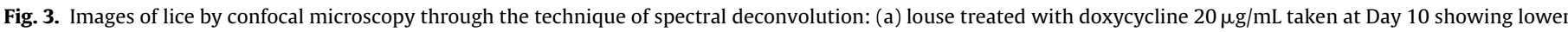

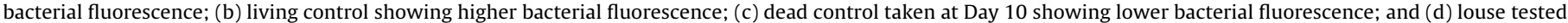
with negative probe showing no bacterial fluorescence.
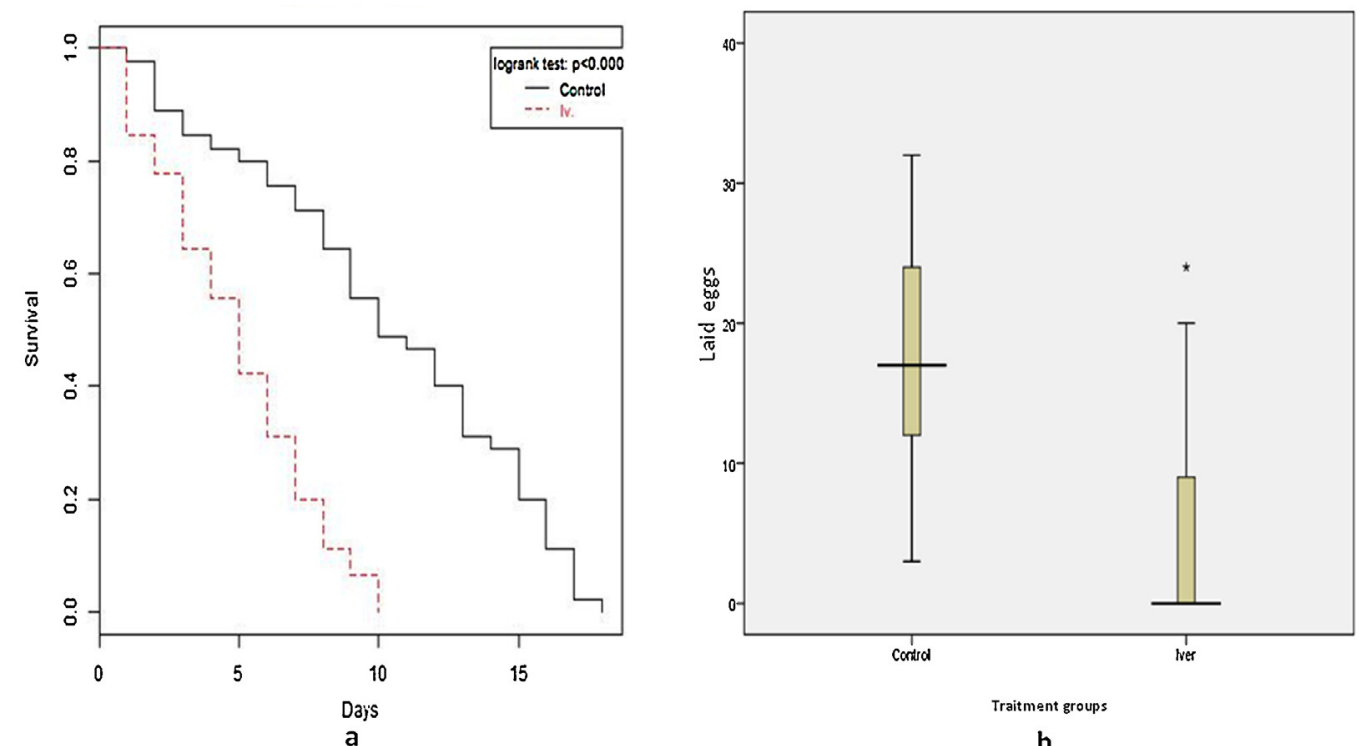

b

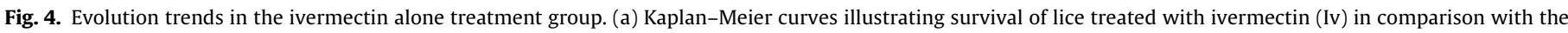
control group. (b) Mean $( \pm 95 \% \mathrm{CI})$ number of eggs laid per day in the ivermectin (Iver)-treated group and the control group. CI, confidence interval.

by a decrease in bacterial fluorescence (Fig. 3a). These results corroborate our previous work showing that doxycycline may affect the endosymbionts of lice through the mycetome switch, thus causing death of the louse [10].

Despite the introduction of some products such as organophosphates, pyrethrins and pyrethroids, insecticide resistance remains an increasing problem in many insect vectors of disease [14], especially among lice. Expression levels of $\mathrm{ABC}$ transporters have also been associated with drug resistance in arthropods and nematodes. Overexpression of these ABC transporters is associated with ivermectin resistance in Haemonchus contortus [16], Caenorhabditis elegans [17], P. h. humanus [28], Sarcoptes scabiei [29] and
R. microplus [18]. In a cohort of homeless subjects in Marseilles (France), a prevalence of body lice of $85 \%$ was observed [30]. This infestation was reduced temporarily to $19 \%$ with three doses of oral ivermectin administered at 7-day intervals. However, treatment failure or early recrudescence is common following ivermectin alone, and multiple doses are usually required to achieve a cure [31]. Moreover, in their randomised trial Chosidow et al. suggest that ivermectin could be an alternative treatment [32], but its transient effect was also demonstrated in some studies [3]. The findings of the current study show the transient effect of ivermectin alone on lice with a monitoring time of 10 days, associated with a slow decrease in the production of nits (Fig. 4; Supplementary Table S2). 

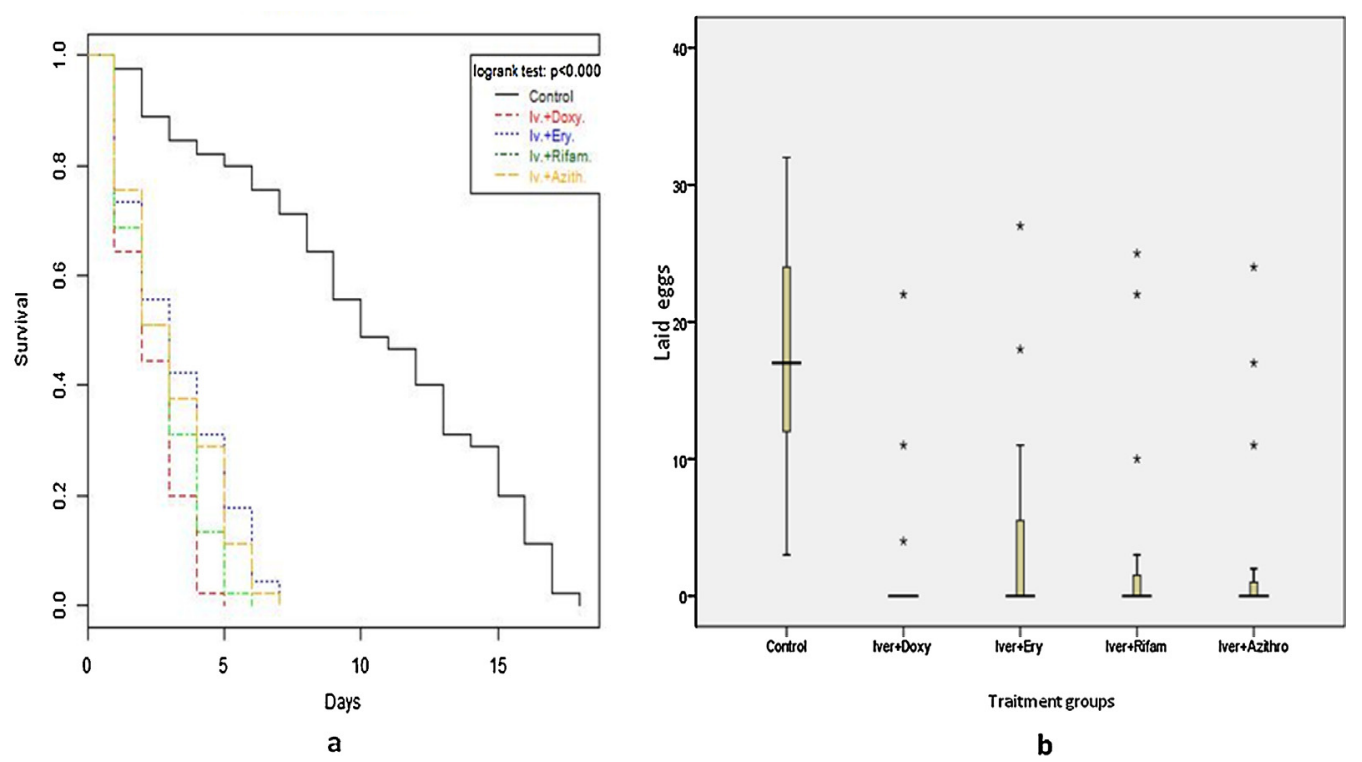

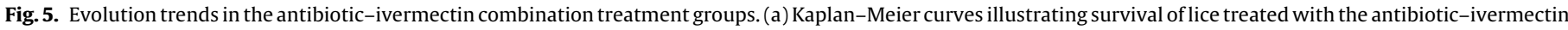

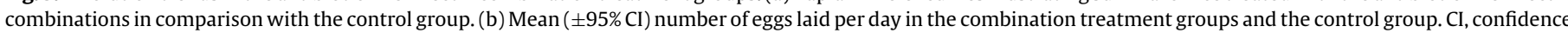
interval; Iv/Iver, ivermectin; Doxy, doxycycline; Ery, erythromycin; Rifam, rifampicin; Azith/Azithro, azithromycin.
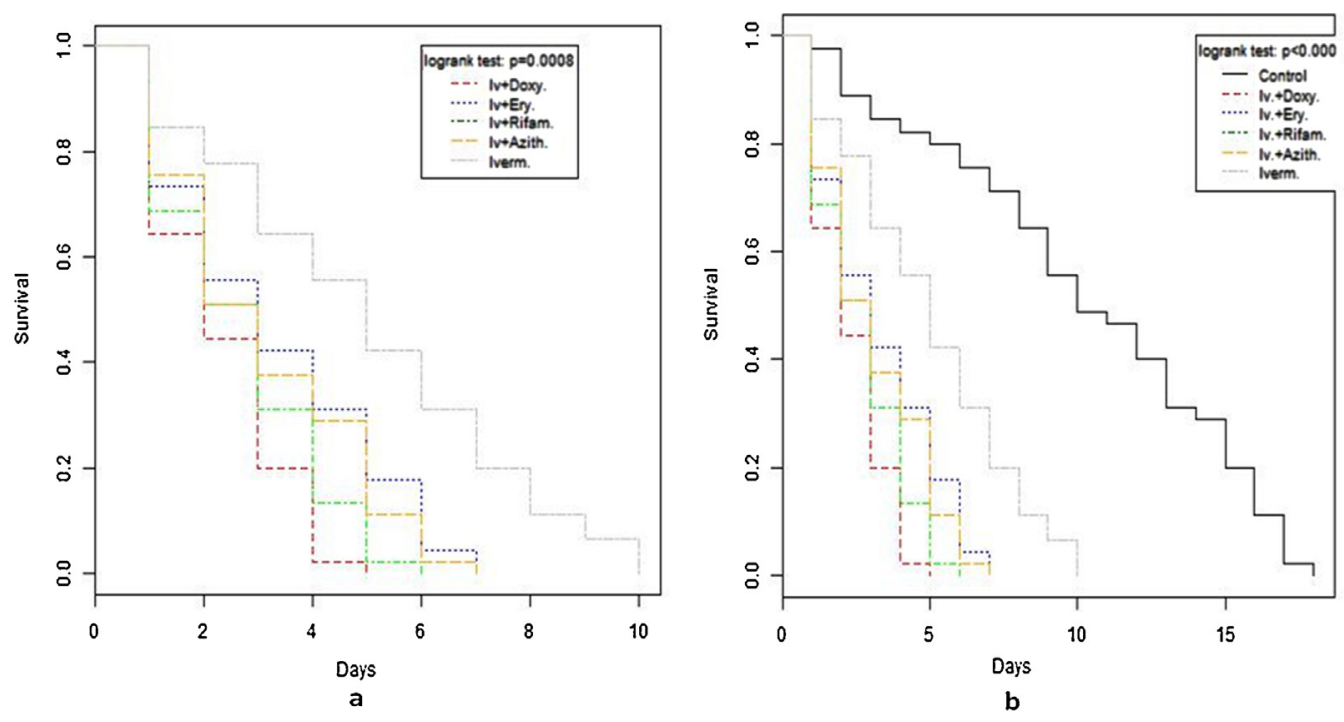

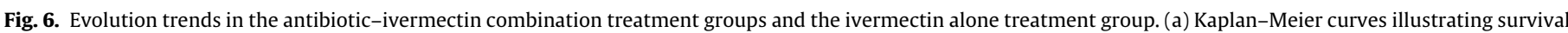

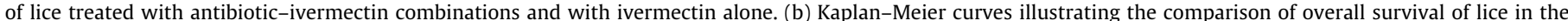

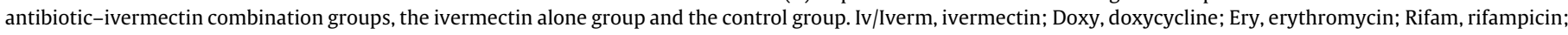
Azith, azithromycin.

Thus, in light of these various therapeutic failures, we may conclude that ivermectin could be useful with other drugs of different classes especially antibiotics, in the control of body lice infestation.

The efficacy of drug combination with ivermectin has been demonstrated in nematodes [33] and ectoparasites [34]. For ivermectin, it was suggested that head lice may be more susceptible than body lice; this could be justified by the model of Mumcuoglu et al., who observed high mortality of nymphs and female body lice fed on rabbits treated with $200 \mu \mathrm{g} / \mathrm{kg}$ ivermectin for 3 days, followed by a sharp decline reaching the level of the controls on Day 6 [35]. In light of the various therapeutic failures described in lice, we decided test antibiotic combinations with ivermectin. In the second series of in vitro experiments, we were able to demonstrate the antiparasitic synergistic activity of a combination of several drugs. The monitoring time ranged from 5 days to 7 days in the combination group, whilst that of ivermectin alone was 10 days (Supplementary Table S2). Interestingly, the difference in overall survival of lice in the combination treatment groups compared with ivermectin alone was also significant. Thus, these results highlight the efficacy of drug combinations compared with ivermectin alone. In the literature, compounds including antibiotics have been shown to increase intracellular concentrations of macrocyclic lactones [36]. In addition, it was shown that drug combinations including ivermectin provide antifilarial activity with ancillary benefits on intestinal helminths and ectoparasites such as chiggers and lice [34]. When doxycycline was combined with macrocyclic lactones in adult worms, ivermectin efficacy was ca. 80\% compared with $9 \%$ when treatment was performed with doxycycline alone [37]. Hoerauf et al. recommend concurrent administration of ivermectin with doxycycline in the treatment of Onchocerca worms carrying 
Wolbachia endobacteria [38], and later Coulibaly et al. found a significant reduction of circulating antigen levels of Wuchereria bancrofti in groups treated with a combination of doxycycline plus ivermectin for 12 months [39]. The effect of this combination has also been confirmed in dogs naturally infected with Dirofilaria immitis [40]. Thus, the current results are in agreement with the literature, especially that of Guo et al., which identifies for the first time that avermectin (macrocyclic lactone derivative including ivermectin) could act synergistically with meticillin (an antibiotic) to kill bacteria (MRSA) [23]. In addition, the current study demonstrates the first synergistic association of these drugs in vitro against body lice. We believe that the synergistic effect of combinations of antibiotics plus ivermectin could be used to achieve complete eradication of lice and to avoid the selection of a resistant population of lice.

\section{Conclusion}

The present study demonstrates a synergistic effect of antibiotics combined with ivermectin to even more effectively control lice. Thus, it would be interesting to develop this model in vivo in the control of lice infestation in humans.

\section{Acknowledgement}

The authors are grateful to Jean-Michel Berenger for technical support.

Funding: This work was supported by 'IHU Méditerranée Infection' (Marseille, France).

Competing interests: None declared.

Ethical approval: Ethical approval for the use of human blood in vitro was obtained from the Laboratory Research Ethics Board of Molecular Hematology, French Blood Service (EFS).

Patent: Title: 'Composed and combination of compounds for the treatment of lice'. Year of submission: 2014.

\section{References}

[1] Raoult D, Roux V. The body louse as a vector of reemerging human diseases. Clin Infect Dis 1999;29:888-911.

[2] Meinking TL, Taplin D. Infestations: pediculosis. Curr Probl Dermatol 1996;24:157-63.

[3] Brouqui P, Stein A, Dupont HT, Gallian P, Badiaga S, Rolain JM, et al. Ectoparasitism and vector-borne diseases in 930 homeless people from Marseilles. Medicine (Baltimore) 2005;84:61-8.

[4] Cutler SJ, Abdissa A, Trape JF. New concepts for the old challenge of African relapsing fever borreliosis. Clin Microbiol Infect 2009;15:400-6.

[5] Piarroux R, Abedi AA, Shako JC, Kebela B, Karhemere S, Diatta G, et al. Plague epidemics and lice, Democratic Republic of the Congo. Emerg Infect Dis 2013:19:505-6.

[6] Raoult D, Ndihokubwayo JB, Tissot-Dupont H, Roux V, Faugere B, Abegbinni $\mathrm{R}$, et al. Outbreak of epidemic typhus associated with trench fever in Burundi. Lancet 1998;352:353-8.

[7] Butler T, Jones PK, Wallace CK. Borrelia recurrentis infection: single-dose antibiotic regimens and management of the Jarisch-Herxheimer reaction. J Infect Dis 1978; 137:573-7.

[8] Ohl ME, Spach DH. Bartonella quintana and urban trench fever. Clin Infect Dis 2000;31:131-5

[9] Raoult D, Drancourt M. Antimicrobial therapy of rickettsial diseases. Antimicrob Agents Chemother 1991;35:2457-62.

[10] Sangaré AK, Boutellis A, Drali R, Audoly G, Weber P, Rolain JM, et al. Doxycycline kills human lice through its activity on their bacterial symbiont. Int J Antimicrob Agents 2015;45:675-6.

[11] Gratz NG. Treatment resistance in louse control. In: Orkin M, Maibach H, editors. Cutaneous infestations and insect bites. New York, NY: Marcel Dekker; 1985. p. 219-30.
[12] Hurlbut HS, Altman RM, Nibley Jr C. DDT resistance in Korean body lice. Science 1952;115:11-2.

[13] Kitaoka M. DDT-resistant louse in Tokyo. Jpn J Med Sci Biol 1952;5:75-88.

[14] Hemingway J, Ranson $\mathrm{H}$. Insecticide resistance in insect vectors of human disease. Annu Rev Entomol 2000;45:371-91.

[15] Dourmishev AL, Dourmishev LA, Schwartz RA. Ivermectin: pharmacology and application in dermatology. Int J Dermatol 2005;44:981-8.

[16] Xu M, Molento M, Blackhall W, Ribeiro P, Beech R, Prichard R. Ivermectin resistance in nematodes may be caused by alteration of P-glycoprotein homolog. Mol Biochem Parasitol 1998;91:327-35.

[17] James CE, Davey MW. Increased expression of ABC transport proteins is associated with ivermectin resistance in the model nematode Caenorhabditis elegans. Int J Parasitol 2009;39:213-20.

[18] Pohl PC, Klafke GM, Carvalho DD, Martins JR, Daffre S, da Silva Vaz Jr I, et al ABC transporter efflux pumps: a defense mechanism against ivermectin in Rhipicephalus (Boophilus) microplus. Int J Parasitol 2011;41:1323-33.

[19] Lasota JA, Dybas RA. Avermectins, a novel class of compounds: implications for use in arthropod pest control. Annu Rev Entomol 1991:36:91-117.

[20] Perez-Cogollo LC, Rodriguez-Vivas RI, Ramirez-Cruz GT, Miller RJ. First report of the cattle tick Rhipicephalus microplus resistant to ivermectin in Mexico. Vet Parasitol 2010;168:165-9.

[21] Scott JG. Cross-resistance to the biological insecticide abamectin in pyrethroidresistant house flies. Pestic Biochem Physiol 1989;34:27-31.

[22] Currie BJ, Harumal P, McKinnon M, Walton SF. First documentation of in vivo and in vitro ivermectin resistance in Sarcoptes scabiei. Clin Infect Dis 2004;39:e8-12.

[23] Guo H, Ren B, Dai H, Dai S, Zhang Y, Liu Y, et al. Reversal of meticillin resistance in Staphylococcus aureus by the anthelmintic avermectin. Int J Antimicrob Agents 2014;44:274-6.

[24] Kirkness EF, Haas BJ, Sun W, Braig HR, Perotti MA, Clark JM, et al. Genome sequences of the human body louse and its primary endosymbiont provide insights into the permanent parasitic lifestyle. Proc Natl Acad Sci U S A 2010;107:12168-73.

[25] Culpepper GH. Rearing and maintaining a laboratory colony of body lice on rabbits. Am J Trop Med Hyg 1948;28:499-504.

[26] Buchner P. Symbiosis in luminous animals. In: Buchner P, editor. Endosymbiosis of animals with plant microorganisms. New York, NY: Interscience Publishers; 1965. p. 543-71.

[27] Perotti MA, Allen JM, Reed DL, Braig HR. Host-symbiont interactions of the primary endosymbiont of human head and body lice. FASEB J 2007;21:1058-66.

[28] Yoon KS, Strycharz JP, Baek JH, Sun W, Kim JH, Kang JS, et al. Brief exposures of human body lice to sublethal amounts of ivermectin over-transcribes detoxification genes involved in tolerance. Insect Mol Biol 2011:20:687-99.

[29] Mounsey KE, Pasay CJ, Arlian LG, Morgan MS, Holt DC, Currie BJ, et al. Increased transcription of glutathione $\mathrm{S}$-transferases in acaricide exposed scabies mites. Parasit Vectors 2010:3:43.

[30] Foucault C, Ranque S, Badiaga S, Rovery C, Raoult D, Brouqui P. Oral ivermectin in the treatment of body lice. J Infect Dis 2006;193:474-6.

[31] Huffam SE, Currie BJ. Ivermectin for Sarcoptes scabiei hyperinfestation. Int Infect Dis 1998;2:152-4.

[32] Chosidow O, Giraudeau B, Cottrell J, Izri A, Hofmann R, Mann SG, et al. Oral ivermectin versus malathion lotion for difficult-to-treat head lice. N Engl J Med 2010;362:896-905

[33] Passeri B, Vismarra A, Cricri G, Bazzocchi C, Kramer L, Bacci C. The adulticide effect of a combination of doxycycline and ivermectin in Dirofilaria immitisexperimentally infected dogs is associated with reduction in local $\mathrm{T}$ regulatory cell populations. Vet Parasitol 2014:205:208-10.

[34] Munirathinam A, Sunish IP, Rajendran R, Tyagi BK. Impact of ivermectin drug combinations on Pediculus humanus capitis infestation in primary schoolchildren of south Indian rural villages. Int J Dermatol 2009;48:1201-5.

[35] Mumcuoglu KY, Miller J, Rosen LJ, Galun R. Systemic activity of ivermectin on the human body louse (Anoplura: Pediculidae). J Med Entomol 1990;27:72-5.

[36] Dupuy J, Lespine A, Sutra JF, Alvinerie M. Fumagillin, a new P-glycoproteininterfering agent able to modulate moxidectin efflux in rat hepatocytes. J Vet Pharmacol Ther 2006;29:489-94.

[37] Menozzi A, Bertini S, Turin L, Serventi P, Kramer L, Bazzocchi C. Doxycycline levels and anti-Wolbachia antibodies in sera from dogs experimentally infected with Dirofilaria immitis and treated with a combination of ivermectin/doxycycline. Vet Parasitol 2015;209:281-4.

[38] Hoerauf A, Mand S, Volkmann L, Büttner M, Marfo-Debrekyei Y, Taylor M, et al. Doxycycline in the treatment of human onchocerciasis: kinetics of Wolbachia endobacteria reduction and of inhibition of embryogenesis in female Onchocerca worms. Microbes Infect 2003;5:261-73.

[39] Coulibaly YI, Dembele B, Diallo AA, Lipner EM, Doumbia SS, Coulibaly SY, et al. A randomized trial of doxycycline for Mansonella perstans infection. N Engl J Med 2009;361:1448-58.

[40] Grandi G, Quintavalla C, Mavropoulou A, Genchi M, Gnudi G, Bertoni G, et al. A combination of doxycycline and ivermectin is adulticidal in dogs with naturally acquired heartworm disease (Dirofilaria immitis). Vet Parasitol 2010;169:347-51. 